\title{
ANALISIS KESALAHAN BERBAHASA PADA PENULISAN MEDIA LUAR RUANG DI WILAYAH KOTA MEDAN
}

\author{
NIKMAH SARI HASIBUAN \\ Universitas Negeri Medan \\ Email:nikmahsari92@gmail.com \\ No Hp 08126041 1505/ \\ 085372955656 \\ Fb:Nikmah Sari
}

\begin{abstract}
Abstrak
Bahasa merupakan peran penting dalam proses komunikasi. Seseorang dalam berkomunikasi dengan satu sama lain dengan menggunakan bahasa, baik lisan atau bahasa tertulis. Bahasa dapat digunakan di semua tempat, termasuk media luar ruang, yang di toko papan nama, billboard, spanduk, dan lembaga signage. Contoh bahasa adalah suatu bentuk komunikasi yang pengiriman menulis. Menulis di media luar ruang di wilayah Kota Medan masih ditemukan banyak kesalahan, baik dari segi penulisan kesalahan ejaan, tanda baca, dan pilihan kata (diksi). Oleh karena itu, penelitian ini bertujuan untuk menganalisis kesalahan penulisan di Kota media luar ruang di Medan. Pendekatan yang digunakan dalam penelitian ini adalah pendekatan teoritis dan metodologis. Pendekatan teoritis dalam penelitian ini menggunakan analisis pendekatan kesalahan bahasa Indonesia, sedangkan pendekatan metodologis yang digunakan adalah pendekatan deskriptif kualitatif. Pengumpulan data dilakukan dengan menggunakan metode observasi langsung (observasi), catatan teknis, dan dokumentasi. Analisis data menggunakan teknik pemilahan dan ganti teknik. Presentasi menggunakan metode informal analisis data. Hasil yang diperoleh masih banyak kesalahan menulis di media luar ruang di Kota Medan yang tidak sesuai dengan aturan Indonesia. Di antara kesalahan penulisan menulis kesalahan ejaan, tanda baca, dan pilihan kata (diksi).
\end{abstract}

Kata kunci: ejaan, diksi, tanda baca, kesalahan bahasa

\begin{abstract}
Language plays an important role in the communication process. Someone in communicating with one another by means of language, either spoken or written language. Language can be used in all places, including the outdoor media, which is on the nameplate stores, billboards, banners, and signage agencies. Examples of the language is a form of communication which delivery is writing. Writing on outdoor media in the region of Medan City still found a lot of errors, both in terms of writing errors of spelling, punctuation, and word choice (diction). Therefore, this study aims to analyze the writing errors in City of outdoor media in Medan. The approach used in this study is a theoretical and methodological approach. The theoretical approach in this study using Indonesian language error analysis approach, while the methodological approach used is descriptive qualitative approach. Data collection is performed using the method of direct observation (observation), technical notes, and documentation. Analysis of the data using sorting technique and dressing techniques. The presentations using informal methods of data analysis. The results obtained are still a lot of mistakes writing on outdoor media in Medan city that does not comply with the rules of Indonesian. Among the writing mistakes writing errors of spelling, punctuation, and word choice (diction).
\end{abstract}

Keywords: spelling, diction, punctuation, language errors 


\section{PENDAHULUAN}

Bahasa memegang peranan penting dalam proses komunikasi. Peran tersebut akan mampu memainkan fungsinya jika dalam tuturan akan tercipta komunikasi yang baik. Kegiatan bertutur selalu melibatkan dua hal utama, yaitu penutur (komunikator) dan petutur (komunikan). Kegiatan bertutur pada dasarnya akan selalu hadir di tengah-tengah masyarakat. Hal ini dikarenakan kegiatan bertutur merupakan sarana berinteraksi masyarakat satu dengan lainnya.

Bahasa sebagai hasil bertutur mempunyai beragam fungsi dalam kehidupan bermasyarakat. Bahasa juga berperan dalam menyatukan masyarakat. Kehidupan yang dipenuhi semangat kekeluargaan akan mampu terwujud jika antarmasyarakat mampu berkomunikasi dengan baik. Tidak bisa diingkari bahwa alat komunikasi yang mampu mewujudkan tersebut adalah bahasa. Bahasa juga merupakan media bagi setiap manusia untuk menyampaikan ide, pikiran, gagasan, konsep, dan perasaan.

Kehidupan masyarakat yang majemuk menimbulkan sebuah perilaku yang berbeda. Perbedaan ini tidak dapat dipungkiri, sehingga menciptakan sebuah proses komunikasi yang beragam. Proses komunikasi inilah yang dinamakan tindak ujar atau tindak tutur. Tindak ujar atau tindak tutur adalah kajian tuturan berdasarkan makna atau arti tindakan dalam tuturannya (Chaer dan Agustina, 2004: 65).

Dalam hubungan dengan kehidupan masyarakat, bahasa Indonesia telah terjadi berbagai perubahan. Terutama yang berkaitan dengan tatanan baru kehidupan dunia dan perkembangan ilmu pengetahuan serta teknologi, khususnya teknologi informasi yang semakin sarat dengan tuntutan dan tantangan globalisasi. Kondisi itu telah menempatkan bahasa Asing terutama bahasa Inggris pada posisi strategis yang memngkinkan bahasa itu memasuki berbagai sendi kehidupan bangsa dan mempengaruhi perkembangan bahasa Indonesia. Selain bahasa asing, penggunaan bahasa daerah khususnya bahasa Melayu Jakarta dan bahasa "gaul" telah mewarnai penggunaan bahasa Indonesia lisan. Bahkan, bahasa iklan sangat diwarnai oleh penggunaan bahasa daerah tersebut. Penggunaan bahasa asing dan bahasa daerah tersebut telah mempengaruhi cara pikir masyarakat Indonesia dalam berbahasa Indonesia resmi. Kondisi itulah yang menyebabkan terjadinya kesalahan berbahasa Indonesia. Untuk 
itu, diperlukan tata cara penggunaan bahasa Indonesia yang baik dan benar. Atas dasar tersebut, peneliti ingin memberikan pengetahuan tentang perkembangan Bahasa Indonesia dalam fenomena pemilihan diksi yang tepat dalam proses komunikasi, baik secara lisan maupun dalam tulisan.

Penelitian ini dimaksudkan untuk menganalisis kesalahan berbahasa Indonesia pada penulisan media luar ruang di wilayah Kota Medan. Objek penelitiannya adalah penulisan pada papan nama pertokoan, papan nama instansi, baliho, dan spanduk yang ada di wilayah Kota Medan. Peneliti memilih media luar ruang yang ada di Medan sebagai tempat penelitian berdasarkan tempat tinggal. Di wilayah Medan ini banyak sekali didapati kesalahan penulisan pada papan nama pertokoan, papan nama instansi, baliho, dan spanduk. Untuk itu, peneliti tergerak untuk melakukan penelitian atas berbagai kesalahan penulisan yang tidak sesuai dengan kaidah baku bahasa Indonesia pada media luar ruang tersebut.

Alasan pemilihan penulisan pada media luar ruang di wilayah ini sebagai data penelitian, yaitu pertama media luar ruang seperti baliho dan spanduk lebih mudah ditemukan dibandingkan dengan di media elektronik. Kedua, rentang waktu pemasangannya lebih lama.

Ketiga, media luar ruang menjangkau semua lapisan masyarakat 3 karena pemasangannya dilakukan sampai ke pelosok daerah, sehingga mudah dijumpai di pinggir-pinggir jalan atau di tempat umum. Keempat, penelitian terhadap media luar ruang di wilayah Kota Medan sejauh pengetahuan peneliti belum pernah dilakukan.

\section{KAJIAN LITERATUR DAN PENGEMBANGAN HIPOTESIS}

\section{Analisis Kesalahan Bahasa Indonesia}

Dalam bahasa Indonesia terdapat beberapa kata yang artinya bernuansa dengan kesalahan, yaitu; penyimpangan, pelanggaran, dan kekhilafan. Keempat kata itu dapat dideskripsikan artinya sebagai berikut.

1) Kata 'salah' diantonimkan dengan 'betul', artinya apa yang dilakukan tidak betul, tidak menurut norma, tidak menurut aturan yang ditentukan. Hal tersebut mungkin disebabkan oleh pemakai bahasa yang belum tahu atau tidak tahu terdapat norma, kemungkinan yang lain adalah kekhilafan. Jika kesalahan ini dikaitkan dengan 
penggunaan kata, ia tidak tahu kata yang tepat dipakai.

2) 'Penyimpangan' dapat diartikan menyimpang dari norma yang telah ditetapkan. Pemakai bahasa menyimpang karena tidak mau, enggan, malas mengikuti norma yang ada. Sebenarnya, pemakai bahasa tersebut tahu norma yang benar, tetapi dia memakai norma lain yang dianggap lebih sesuai dengan konsepnya. Kemungkinan lain penyimpangan disebabkan oleh keinginan yang kuat yang tidak dapat dihindari karena satu dan lain hal. Sikap berbahasa ini cenderung menuju ke pembentukkan kata, istilah, slang, jargon, bisa juga prokem.

3) 'Pelanggaran' terkesan negatif karena pemakai bahasa dengan penuh kesadaran tidak mau menurut norma yang telah ditentukan, sekalipun dia mengetahui bahwa yang dilakukan berakibat tidak baik. Sikap tidak disiplin terhadap media yang digunakan seringkali tidak mampu menyampaikan pesan dengan tepat.

4) 'Kekhilafan' merupakan proses psikologis yang dalam hal ini menandai seseorang khilaf menerapkan teori atau norma bahasa yang ada pada dirinya, khilaf mengakibatkan sikap keliru memakai. Kekhilafan dapat diartikan kekeliruan. Kemungkinan salah ucap, salah susun karena kurang cermat (Setyawati, 2010:1314).

Apa yang dimaksud kesalahan berbahasa? Terdapat dua ukuran dalam menjawab pertanyaan tersebut, yaitu:

(1) Berkaitan dengan faktor-faktor penentu dalam berkomunikasi. Faktor-faktor penentu dalam berkomunikasi itu adalah: siapa yang berbahasa dengan siapa, untuk tujuan apa. Dalam situasi apa (tempat dan waktu), dalam konteks apa (peserta lain, kebudayaan, dan suasana), dengan jalur apa (lisan atau tulisan), dengan media apa (tatap muka, telepon, surat, kawat, buku, koran, dan sebagainya), dalam peristiwa apa (bercakapcakap, ceramah, upacara, laporan, lamaran, kerja, pernyataan cinta, dan sebagainya).

(2) Berkaitan dengan aturan atau kaidah kebahasaan yang dikenal dengan istilah tata bahasa (Depdikbud dalam Setyawati, 2010:14-15)

Jadi, kesimpulannya bahwa kesalahan berbahasa adalah penggunaan 
bahasa baik secara lisan maupun tertulis yang menyimpang dari faktor-faktor penentu berkomunikasi atau menyimpang dari norma kemasyarakatan dan menyimpang dari kaidah tata bahasa Indonesia.

Menurut Tarigan dalam Setyawati (2010:19-20), kesalahan berbahasa dalam bahasa Indonesia dapat diklarifikasikan menjadi:

(1) berdasarkan tataran linguistik, kesalahan berbahasa dapat diklarifikasikan menjadi: kesalahan berbahasa di bidang fonologi, morfologi, sintaksis (frasa, klausa, kalimat), semantik, dan wacana;

(2) berdasarkan kegiatan berbahasa atau keterampilan berbahasa dapat diklarifikasikan menjadi kesalahan berbahasa dalam menyimak, berbicara, membaca, dan menulis;

(3) berdasarkan sarana atau jenis bahasa yang digunakan dapat berwujud kesalahan berbahasa secara lisan dan secara tertulis;

(4) berdasarkan penyebab kesalahan tersebut terjadi dapat diklarifikasikan menjadi kesalahan berbahasa karena pengajaran dan kesalahan berbahasa karena interferensi; dan

(5) kesalahan berbahasa berdasarkan frekuensi terjadinya dapat diklarifikasikan atas kesalahan berbahasa yang paling sering, sering, sedang, kurang, dan jarang terjadi.

\section{Ejaan}

Biasanya ejaan itu bukan hanya soal perlambangan fonem dengan huruf saja, tetapi juga mengatur cara penulisan kata dan penulisan kalimat beserta dengan tanda-tanda bacanya (Chaer, 2006:36). Sejalan dengan pendapat Chaer, Setyawati (2010:155) juga mengatakan bahwa ejaan tidak hanya berkaitan dengan cara mengeja suatu kata, tetapi yang lebih utama berkaitan dengan cara mengatur penulisan huruf menjadi satuan yang lebih besar, misalnya penggunaan tanda baca pada satuan-satuan huruf, kata, kelompok kata, atau kalimat. Masalah ejaan pada hakikatnya merupakan kaidah bahasa tulis. Dengan kata lain, ejaan adalah seperangkat aturan tentang keseluruhan sistem penulisan bahasa dengan menggunakan huruf, kata, dan tanda baca sebagai sarananya.

EYD merupakan kaidah yang harus dipatuhi oleh pemakai bahasa demi keteraturan dan keseragaman bentuk, terutama dalam bahasa tulis. Keteraturan bentuk akan berimplikasi pada ketepatan dan kejelasan makna. EYD sangat berperan sebagai pemersatu 
bangsa sebab ejaan yang telah ditetapkan ini merupakan bahasa tulis yang telah resmi digunakan di Indonesia. Selain itu, EYD juga dapat digunakan sebagai pedoman dalam beraktivitas berbahasa terutama dalam berbahasa resmi, baik, dan benar, serta dapat dijadikan sebagai pengendali perkembangan bahasa Indonesia terhadap pengaruh bahasa asing dan IPTEK. Sementara itu, tujuan penggunaan EYD adalah agar penggunaan dan penulisan bahasa sesuai dengan aturan yang berlaku sehingga tidak ada lagi kesenjangan antara pengucapan atau penulisan kalimat dan makna asli dari kalimat tersebut. Kaidah ejaan bahasa Indonesia yang disempurnakan (EYD), meliputi pemakaian huruf, penulisan kata, penulisan unsur serapan, dan pemakaian tanda baca. Berikut ini akan dijelaskan keempat kaidah tersebut.

\section{Pemakaian Huruf}

a) Pemakaian Huruf Kapital

Berdasarkan

Permendiknas

(2009:8-19), terdapat enam belas aturan dalam penggunaan huruf kapital, yaitu sebagai berikut.

(1) Huruf kapital atau huruf besar dipakai sebagai huruf pertama kata pada awal kalimat.

Misalnya:
Dia membaca buku.

Apa maksudnya?

Kita harus bekerja keras.

(2) Huruf kapital dipakai sebagai huruf pertama petikan langsung.

Misalnya:

Adik bertanya, "Kapan kita pulang?"

Orang itu menasehati anaknya, "Berhati-hatilah, nak!"

"Kemarin engkau terlambat," katanya.

(3) Huruf kapital dipakai sebagai huruf pertama dalam kata dan ungkapan yang berhubungan dengan agama, kitab suci, dan Tuhan, termasuk kata ganti untuk Tuhan.

Misalnya:

Islam Quran

Allah Weda

Yang Mahakuasa

Alkitab

Yang Maha Pengasih

Tuhan akan menunjukkan jalan kepada hamba-Nya.

Bimbinglah hamba-Mu, ya Tuhan, ke jalan yang Engkau beri rahmat.

(4) Huruf kapital dipakai sebagai huruf pertama unsur-unsur nama orang. Misalnya: 
Amir Hamzah

Dewi Sartika

Wage Rudolf Supratman

(5) Huruf kapital dipakai sebagai huruf pertama nama bangsa, suku bangsa, dan bahasa.

Misalnya:

bangsa Eskimo

suku Sunda

bahasa Indonesia

(6) Huruf kapital dipakai sebagai huruf pertama semua kata (termasuk semua unsur kata ulang sempurna) di dalam judul buku, majalah, surat kabar, dan makalah, kecuali kata tugas seperti di, ke, dari, dan, yang, dan untuk yang tidak terletak pada posisi awal.

Misalnya:

Saya telah membaca buku Dari Ave Maria ke Jalan Lain ke Roma.

Bacalah majalah Bahasa dan Sastra.

Dia adalah agen surat kabar Sinar Pembangunan.

Ia menyelesaikan makalah

“Asas-Asas Hukum Perdata".

(7) Huruf kapital dipakai sebagai huruf pertama kata Anda yang digunakan dalam penyapaan.

Misalnya:
Sudahkah Anda tahu?

Siapa nama Anda?

\section{b) Pemakaian Huruf Miring}

Waridah

(2008:12-13)

mengemukakan bahwa terdapat tiga aturan dalam pemakaian huruf miring, yaitu sebagai berikut.

1) Huruf miring dalam cetakan dipakai untuk menuliskan nama buku, majalah, dan surat kabar yang dikutip dalam tulisan.

Misalnya:

majalah Bahasa dan Kesusastraan buku Negarakertagama karangan

Prapanca

surat kabar Suara Karya

\section{Gabungan kata}

Menurut Depdikbud (2009:1516), ada beberapa kaidah dalam penulisan gabungan kata, yaitu sebagai berikut.

Gabungan kata berikut ditulis serangkai. Misalnya:

acapkali

adakalanya

alhamdulillah

padahal

\section{Kata Depan di, ke, dan dari}

Menurut Tarigan (tanpa tahun:81-82), kata depan di, ke, dan dari ditulis terpisah dari kata yang mengikutinya, kecuali di dalam 
gabungan kata yang sudah dianggap sebagai satu kata seperti kepada dan daripada.

Misalnya:

Ayah bertugas di kota Bandung.

$D i$ mana ada gula $d i$ situ ada semut.

Setahu saya dia belum pernah bergaul ke tengah masyarakat Karo.

Nenek saya baru datang dari Kabanjahe.

\section{akronim}

\section{Depdikbud}

(2009:19-21)

Akronim ialah singkatan yang berupa gabungan huruf awal, gabungan suku kata, ataupun gabungan huruf, dan suku kata dari deret yang diperlukan sebagai kata.

(1) Akronim nama diri yang berupa gabungan huruf awal dari deret kata ditulis seluruhnya dengan huruf kapital.

Misalnya:

ABRI

Angkatan Bersenjata Republik Indonesia

\section{PASI}

Persatuan Atletik Seluruh Indonesia FKIP

Fakultas Keguruan dan Ilmu Pendidikan

(2) Akronim nama diri yang berupa gabungan suku kata atau gabungan huruf dan suku kata dari deret kata ditulis dengan huruf awal huruf kapital.

Misalnya:

Iwapi

Ikatan Wanita Pengusaha Indonesia Kowani

Kongres Wanita Indonesia

\section{Angka}

Arifin dan Amran (1995:59-61) menyatakan bahwa ada beberapa kaidah dalam penggunaan angka dan lambang, yaitu sebagai berikut.

1) Penulisan lambang bilangan dengan huruf dilakukan sebagai berikut. dua ratus tiga puluh lima (235) tiga perempat $\left(\frac{3}{4}\right)$ tiga dua pertiga $\left(3_{3}^{2}\right)$ delapan tiga perlima $\left(8_{5}^{3}\right)$

2) Penulisan kata bilangan tingkat dapat dilakukan dengan cara berikut. Abad ke-20 ini dikenal juga sebagai abad teknologi.

Presiden Reagan mengirimkan 250 orang wartawan.

3) Penulisan kata bilangan yang mendapat akhiran -an mengikuti cara berikut.

Sutan Takdir Alisyahbana adalah pujangga tahun 30-an. 
Bolehkah saya menukar uang dengan lembaran 1000-an?

Angkatan Balai Pustaka sering disebur Angkatan Tahun 20-an.

Pemakaian Tanda Baca

a) Tanda Titik (.)

Waridah

(2008:28-30)

mengemukakan bahwa terdapat

enam kaidah dalam penggunaan tanda titik, yaitu sebagai berikut.

1) Tanda titik dipakai pada akhir kalimat yang bukan pertanyaan atau seruan.

Misalnya:

Ayahku tinggal di Solo.

\section{b) Tanda Koma (,)}

Waridah

(2008:30-33)

menyatakan bahwa terdapat beberapa aturan penggunaan tanda koma, yaitu sebagai berikut.

1) Tanda koma dipakai di antara unsurunsur dalam suatu perincian atau pembilangan.

2) Tanda koma dipakai untuk memisahkan suatu kalimat setara yang satu dari kalimat setara berikutnya yang didahului oleh kata hubung seperti tetapi, melainkan, dan sedangkan.

3) Tanda koma dipakai untuk memisahkan anak kalimat dengan induk kalimat jika anak kalimat mendahului induk kalimatnya.

\section{c) Tanda Seru (!)}

Tanda seru dipakai sesudah ungkapan atau pernyataan yang berupa seruan atau perintah yang menggambarkan kesungguhan, ketidakpercayaan, ataupun rasa emosi yang kuat.

Misalnya:

Alangkah seramnya peristiwa itu! Bersihkan kamar itu sekarang juga! Masakan! Sampai hati juga ia meninggalkan anak istrinya. (Depdikbud, 2009:48).

\section{d) Tanda Garis Miring (/)}

Berdasarkan Depdikbud (2009:51), tanda garis miring digunakan dalam penulisan-penulisan berikut.

1) Tanda garis miring dipakai dalam nomor surat dan nomor pada alamat dan penandaan masa satu tahun yang terbagi dalam dua tahun takwim.

Misalnya:

No. 7/PK/1973

Jalan Kramat II/10

tahun anggaran 1985/1986

2) Tanda garis miring dipakai sebagai pengganti kata dan, atau, atau tiap. Misalnya:

Mahasiswa/mahasiswi 


\section{Penulisan Unsur Serapan}

Pada dasarnya sebagian kosakata bahasa Indonesia berasal dari bahasa asing yang kemudian disesuaikan penulisannya dalam kaidah bahasa Indonesia sehingga disebut sebagai kata serapan. Berdasarkan taraf integrasinya, unsur pinjaman dalam bahasa Indonesia dapat dibagi atas dua golongan besar. Pertama, unsur pinjaman yang belum sepenuhnya terserap ke dalam bahasa Indonesia, seperti reshuffle, shuttle cock, I'exploitation de I'homme par I'homme. Unsur-unsur ini dipakai dalam konteks bahasa Indonesia, tetapi pengucapannya masih mengikuti cara asing. Kedua, unsur pinjaman yang pengucapan dan penulisannya disesuaikan dengan kaidah bahasa Indonesia. Dalam hal ini diusahakan agar ejaannya hanya diubah seperlunya sehingga bentuk Indonesianya masih dapat dibandingkan dengan bentuk asalnya (Waridah, 2008:16). Menurut Rosidi (2008:10), penyerapan kata dari bahasa asing dapat melalui adopsi, adaptasi, kreasi, dan terjemahan. Melalui adopsi, kata dari bahasa asing langsung diserap ke dalam bahasa Indonesia karena telah 'sesuai' dengan kaidah bahasa Indonesia, misalnya: jarab, jenazah (bahasa Arab); halte, diagram (bahasa Belanda); koh, suhu (bahasa Cina); bola, tinta (bahasa Portugis); dan bus, biodata (bahasa Inggris). Melalui adaptasi, bahasa Indonesia menyerap dari bahasa asing melalui penyesuaian fonem, misalnya: kabil dari qabil, akademis dari academisch, dan garpu dari garfo. Melalui kreasi, bahasa Indonesia menyerap kosakata bahasa asing hanya konsepnya, bukan kemiripan bentuk luarnya atau makna harfiahnya, misalnya parkir gratis dari free parking, jatuh tempo sebagai padanan dari due date, buku petunjuk periklanan sebagai padanan dari advertising directory, dan back street dari sembunyi-sembunyi, sedangkan melalui terjemahan misalnya garis polisi terjemahan dari police line, pertemuan teknik merupakan terjemahan dari technical meeting.

\section{Diksi (Pilihan Kata)}

Pilihan kata atau diksi pada dasarnya adalah hasil dari upaya memilih kata tertentu untuk digunakan dalam kalimat atau wacana. Pemilihan kata dapat dilakukan bila tersedia sejumlah kata yang artinya hampir sama atau bermiripan. Pemilihan kata bukanlah sekedar memilih kata yang tepat, melainkan juga memilih kata yang cocok. Cocok dalam arti sesuai dengan konteks di mana kata itu berada, dan maknanya tidak bertentangan dengan yang nilai rasa masyarakat pemakainya.

Diksi adalah ketepatan pilihan kata. Penggunaan ketepatan pilihan kata dipengaruhi oleh kemampuan pengguna bahasa yang terkait dengan kemampuan mengetahui, memahami, menguasai, dan menggunakan sejumlah kosa kata secara aktif yang dapat mengungkapkan 
gagasan secara tepat sehingga mampu mengomunikasikannya secara efektif kepada pembaca atau pendengarnya.

Keraf dalam Heryati, dkk. (2013:45) menurunkan tiga kesimpulan utama mengenai diksi, antara lain sebagai berikut.

a. Pilihan kata atau diksi mencakup pengertian kata-kata mana yang dipakai untuk menyampaikan gagasan, bagaimana membentuk pengelompokkan kata-kata yang tepat.

b. Pilihan kata atau diksi adalah kemampuan membedakan secara tepat nuansa-nuansa makna dari gagasan yang ingin disampaikan dan kemampuan menemukan bentuk yang sesuai atau cocok dengan situasi dan nilai rasa yang dimiliki kelompok masyarakat pendengar.

c. Pilihan kata yang tepat dan sesuai hanya dimungkinkan penguasaan sejumlah besar kosa kata atau perbendaharaan kata bahasa.

Dari beberapa pendapat di atas dapat disimpulkan bahwa diksi adalah pemilihan dan pemakaian kata oleh pengarang dengan mempertimbangkan aspek makna kata yaitu makna denotatif dan makna konotatif sebab sebuah kata dapat menimbulkan berbagai pengertian.
Menurut Widjono, 2012:126), pengguna bahasa harus pula memperhatikan kesesuaian kata agar tidak merusak makna, suasana, dan siuasi yang hendak ditimbulkan, atau suasana yang sedang berlangsung. Syarat kesesuaian kata:

1. menggunakan ragam baku dengan cermat dan tidak mencampuradukkan penggunaannya dengan kata tidak baku yang hanya digunakan dalam pergaulan;

2. menggunakan kata yang berhuungan dengan nilai sosial dengan cermat;

3. menggunakan kata berpasangan (idiomatik) dan berlawanan makna dengan cermat;

4. menggunakan kata dengan nuansa tertentu;

5. menggunakan kata ilmiah untuk penulisan karangan imiah, dan komunikasi nonilmiah menggunakan kata populer;

6. menghindarkan penggunaan ragam lisan (pergaulan) dalam bahasa tulis.

Selanjutnya, menurut Widjono (2012:128), fungsi diksi yatu:

1. melambangkan gagasan yang diekspresikan secara verbal;

2. membentuk gaya ekspresi gagasan yang tepat (sangat resmi, resmi, 
tidak resmi) sehingga menyenangkan pendengar atau pembaca;

3. menciptakan komunikasi yang baik dan benar;

4. menciptakan suasana yang tepat;

5. mencegah perbedaan penafsiran;

6. mencegah salah pemahaman;

7. mengefektifkan pencapaian target komunikasi.

\section{METODE PENELITIAN}

Penelitian ini menggunakan metode deskriptif. Penggunaan metode tersebut untuk memperoleh deskripsi secara faktual mengenai hal-hal yang akan di teliti yang sedang berlangsung pada masa sekarang. Penelitian yang dilakukan semata-mata hanya berdasarkan fakta yang ada atau fenomena yang ada sehingga yang dihasilkan atau dicatat berupa perincian seperti potret paparan sebagaimana adanya (Sudaryanto 1988:62).

\section{TEKNIK PENGUMPULAN DATA}

Pengumpulan data penelitian ini menggunakan teknik observasi dan teknik catat atau rekam (Mahsun 2005). Teknik ini dilakukan untuk memperoleh data secara langsung dari objek penelitian. Pengamatan dilakukan pada media luar ruang yang terdapat di lokasi penelitian. Data kesaslahan penulisan yang teramati dicatat atau direkam sebagai korpus data.

\section{TEKNIK ANALISIS DATA}

Data yang sudah terkumpul atau data teridentifikasi dicatat dalam korpus data. Selanjutnya, data tersebut diklasifikasikan dan dianalisis berdasarkan aspek dan tipe kesalahan. Sesuai dengan karakteristik data yang ingin diperoleh, penganalisisan data penelitian ini menggunakan teknik kualitatif. Hal ini sesuai dengan karakteristik data yang akan dideskripsikan (Mahsun, 2005). Berkaitan dengan ini, Ellis (dalam Tarigan, 2011: 68) mengemukakan bahwa langkah kerja analisis kesalahan berbahasa adalah mengumpulkan data, mengidentifikasikan data, menjelaskan kesalahan, dan mengevaluasikan

\section{HASIL DAN PEMBAHASAN}

Berdasarkan data-data yang diperoleh di lapangan mengenai kaidah penulisan media luar ruang, banyak ditemukan kesalahan dalam penulisannya yang belum memenuhi kaidah penulisan bahasa Indonesia yang baik dan benar. Berikut ini akan diuraikan data-data yang ditemukan di lapangan, bentuk kesalahanan, serta analisis kesalahan penulisan berdasarkan kaidah kebahasaan. 


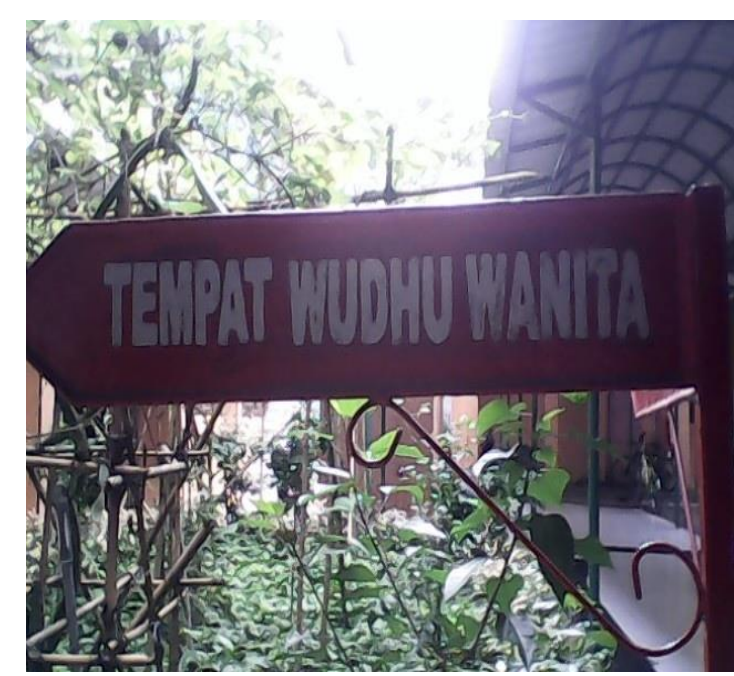

TEMPAT WUDHU WANITA

Konstruksi tersebut salah karena terdapat penulisan kata serapan yang tidak sesuai dengan kaidah kebahasaan. Kesalahan tersebut terdapat pada kata wudhu. Seharusnya kata tersebut ditulis sesuai dengan kaidah ejaan bahasa Indonesia karena berdasarkan kaidah ejaan penulisan dan pengucapan unsurunsur asing disesuaikan dengan kaidah bahasa Indonesia. Dalam hal itu, diusahakan ejaannya disesuaikan dengan Pedoman Umum Pembentukan Istilah Edisi Ketiga agar bentuk Indonesianya masih dapat dibandingkan dengan bentuk asalnya (Waridah, 2008:16). Dengan demikian, pembetulan konstruksi tersebut adalah sebagai berikut.

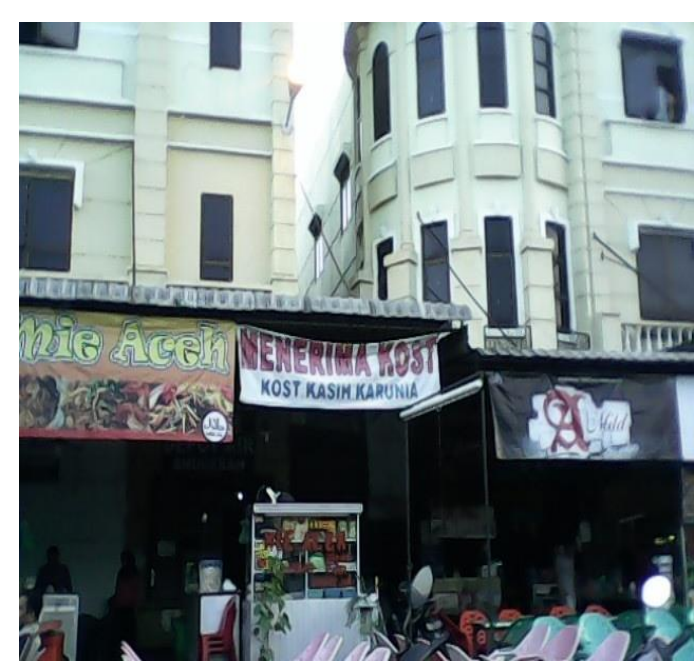

\section{MENERIMA KOST}

KOST KASIH KARUNIA

Kesalahan pada konstruksi tersebut terdapat pada kata kost. Awal tahun 2000, kos ditulis kost sebagai kependekan dari in the kost dari bahasa Belanda yang lalu diserapkan ke dalam bahasa Indonesia menjadi indekos definisinya adalah tinggal di rumah orang lain dengan atau tanpa makan (dengan membayar setiap bulan); memondok (KBBI 2008:531), sedangkan kost dalam bahasa Indonesia yang baku tidak memiliki arti. Dengan demikian, konstruksi tersebut dapat diperbaiki dengan menggantikan kata kost menjadi kos atau indekos. Pembetulannya adalah sebagai berikut.

\section{MENERIMA KOS}

KOS KASIH KARUNIA 


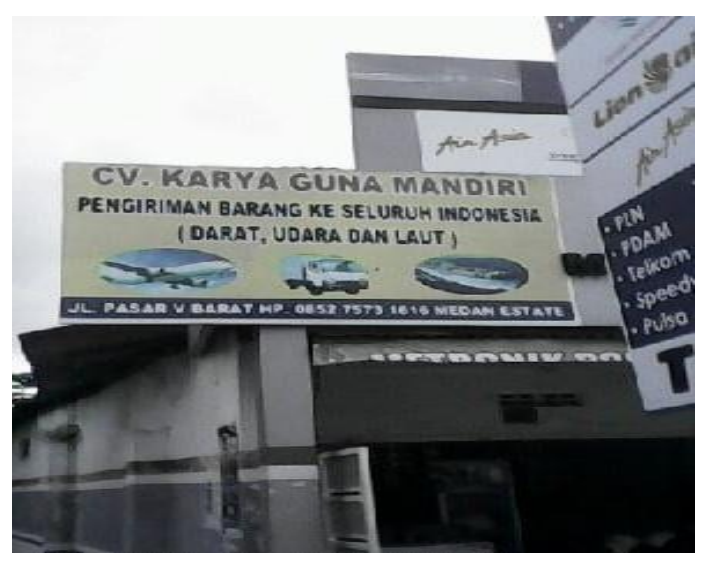

CV. KARYA GUNA MANDIRI

PENGIRIMAN BARANG KE SELURUH INDONESIA

(DARAT, UDARA_DAN LAUT)

Konstruksi tersebut salah karena di antara perincian tidak menggunakan tanda koma. Kesalahan itu terletak di antara kata udara dan laut. Seharusnya di antara perincian digunakan tanda koma karena berdasarkan kaidah ejaan, tanda koma dipakai di antara unsurunsur dalam suatu perincian atau pembilang (Sugiarto, 2013:41). Dengan demikian, konstruksi tersebut dapat diperbaiki dengan memberi tanda koma di setiap perincian. Pembetulannya adalah sebagai berikut.

CV. KARYA GUNA MANDIRI PENGIRIMAN BARANG KE SELURUH INDONESIA (DARAT, UDARA_DAN, LAUT)

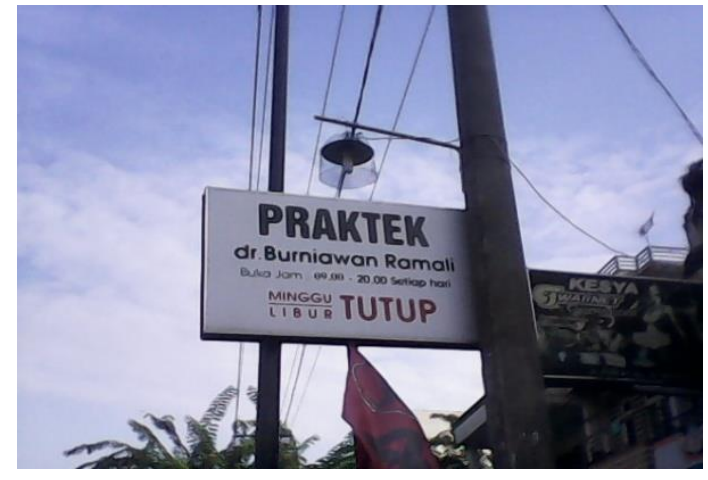

PRAKTEK dr. Burniawan Ramali Buka Jam 09.00 - 20.00 Setiap $\underline{\text { hari }}$

\section{Minggu TUTUP}

Konstruksi tersebut memiliki tiga kesalahan. Kesalahan pertama, yaitu perubahan fonem vokal /i/ menjadi /e/ pada kata praktek. Kata praktek merupakan kata serapan dari bahasa Inggris, yaitu berasal dari kata practice. Seharusnya kata-kata asing yang telah diserap ke dalam bahasa Indonesia ditulis sesuai dengan ejaan bahasa Indonesia karena berdasarkan kaidah ejaan, penulisan dan pengucapan unsurunsur asing disesuaikan dengan kaidah bahasa Indonesia. Dalam hal itu, diusahakan ejaannya disesuaikan dengan Pedoman Umum Pembentukan Istilah Edisi Ketiga agar bentuk Indonesianya masih dapat dibandingkan dengan bentuk asalnya (Waridah, 2008:16). Seharusnya, bentuk baku dari penulisan praktek adalah praktik. Dalam Kamus Besar Bahasa Indonesia kata praktik memiliki arti prak.tik $n$ 1. pelaksanaan 
secara nyata apa yang disebut dalam teori.

Kesalahan kedua terdapat pada kata jam. kata tersebut merupakan kesalahan berbahasa tataran semantik dalam penggunaan kata jam dan pukul. Konstruksi tersebut sebaiknya menggunakan kata pukul karena berdasarkan KBBI (2008:1113) pukul adalah $n$ saat yang menyatakan waktu, sedangkan kata jam dalam KBBI (2008:561) adalah $n 1$ alat untuk mengukur waktu; 2 waktu yang lamanya 1/24 hari.

Kesalahan ketiga terdapat pada frasa setiap hari. Frasa tersebut menyatakan hari Senin samapai Minggu, sedangkan pada konstruksi tersebut disebutkan bahwa hari Minggu tutup, sehingga terdapat ketidaksesuaian atau tidak adanya konsistensi dalam penyampaian informasi. Dengan demikian, konstruksi tersebut dapat diperbaiki dengan menggantikan kata praktek menjadi praktik, menggantikan kata jam menjadi pukul, dan menghilangkan frasa setiap hari. Pembetulannya adalah sebagai berikut.

PRAKTIK

dr. Burniawan Ramali

Buka Pukul 09.00-20.00

Minggu TUTUP

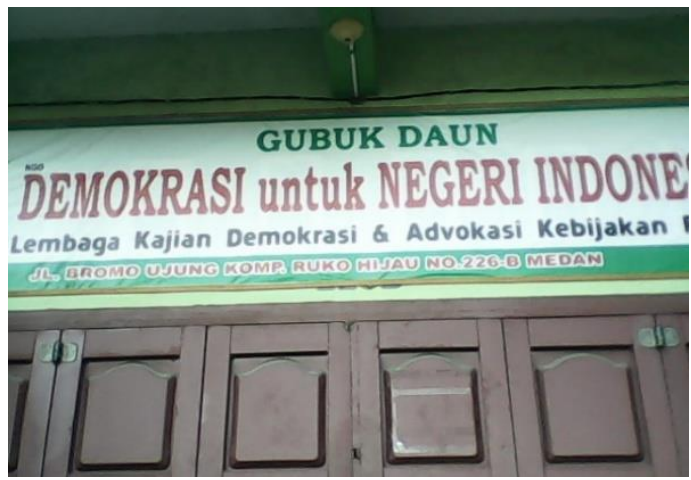

\section{GUBUK DAUN DEMOKRASI untuk NEGERI INDONESIA \\ Lembaga Kajian Demokrasi \& Advokasi Kebijakan JL. BROMO UJUNG_KOMP. RUKO HIJAU_NO.266B_MEDAN}

Konstruksi tersebut memiliki dua kesalahan. Pertama, konstruksi tersebut salah karena terdapat penggunaan huruf kecil yang tidak tepat. Kesalahan tersebut terdapat pada kata untuk. Seharusnya kata tersebut tidak menggunakan huruf kecil, tetapi huruf kapital karena konstruksi tersebut seluruhnya menggunakan huruf kapital atau dapat pula seluruhnya digunakan huruf kapital hanya di setiap huruf pertama kata karena berdasarkan kaidah ejaan, huruf kapital dipakai sebagai huruf pertama semua kata di dalam judul buku, majalah, lembaga resmi, termasuk pada papan nama, kecuali kata tugas, seperti dan, oleh, atau, dan untuk (Sugiarto, 2013). Kedua, konstruksi tersebut salah karena tidak menggunakan tanda koma pada bagian alamat. Seharusnya bagian alamat yang 
disebutkan secara berurutan menggunakan tanda koma karena menurut kaidah ejaan, tanda koma dipakai di antara (a) nama dan alamat, (b) bagian-bagian alamat, (c) tempat dan tanggal, serta (d) nama tempat dan wilayah atau negeri yang ditulis secara berurutan (Sugiarto, 2013:44). Dengan demikian, konstruksi tersebut dapat diperbaiki dengan menggantikan huruf kecil pada kata untuk menjadi huruf kapital dan menggunakan tanda koma di antara bagian alamat. Pembetulannya adalah sebagai berikut.

\section{GUBUK DAUN \\ DEMOKRASI UNTUK NEGERI INDONESIA \\ Lembaga Kajian Demokrasi \& Advokasi Kebijakan JL. BROMO UJUNG, KOMP. RUKO HIJAU, NO.266B, MEDAN}

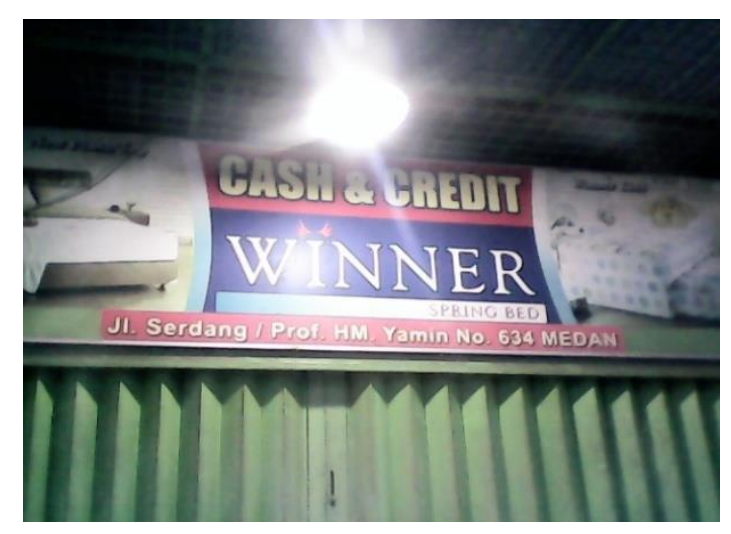

$\underline{\text { CASH \& CREDIT }}$ WINNER J1. Serdang / Prof. HM. Yamin_No. 634 MEDAN
Konstruksi tersebut memiliki empat kesalahan. Pertama, konstruksi tersebut menggunakan kosakata bahasa asing yaitu pada kata cash dan credit. Seharusnya kata-kata asing yang telah diserap ke dalam bahasa Indonesia ditulis sesuai dengan ejaan bahasa Indonesia karena berdasarkan kaidah ejaan, penulisan dan pengucapan unsurunsur asing disesuaikan dengan kaidah bahasa Indonesia. Pemerintah telah mengeluarkan aturan kebahasaan yang terangkum dalam Undang-undang Nomor 24 Tahun 2009 pasal 38 dalam Rahardian (2014:153) menyatakan bahwa "Bahasa Inonesia wajib digunakan dalam rambu umum, spanduk, dan alat informasi lain yang merupakan pelayanan umum”. Dalam hal itu, diusahakan ejaannya disesuaikan dengan Pedoman Umum Pembentukan Istilah Edisi Ketiga agar bentuk Indonesianya masih dapat dibandingkan dengan bentuk asalnya (Waridah, 2008:16). Kedua, kontrusksi tersebut menggunakan spasi di antara kata dan tanda garis miring. Seharusnya sebelum dan sesudah tanda garis miring tidak disisipkan spasi karena berdasarkan kaidah ejaan, spasi digunakan setelah tanda seru, tanda tanya, dan tanda titik untuk memulai kalimat baru. Ketiga, konstruksi tersebut tidak menggunakan 
tanda koma pada bagian alamat. Seharusnya bagian alamat yang disebutkan secara berurutan menggunakan tanda koma karena menurut kaidah ejaan, tanda koma dipakai di antara (a) nama dan alamat, (b) bagian-bagian alamat, (c) tempat dan tanggal, serta (d) nama tempat dan wilayah atau negeri yang ditulis secara berurutan (Sugiarto, 2013:44). Keempat, konstruksi salah karena menggunakan huruf kapital pada kata MEDAN. Seharusnya huruf kapital hanya digunakan pada awal kata Medan karena berdasarkan kaidah ejaan, huruf kapital dipakai sebagai huruf pertama unsurunsur nama diri geografi (Sugiarto, 2013:11). Dengan demikian, konstruksi tersebut dapat diperbaiki dengan menggantikan kata cash dan credit menjadi kata kes dan kredit, menghilangkan spasi di antara kata dan tanda garis miring, menggunakan tanda koma di setiap bagian alamat, dan menggunakan huruf kapital hanya di awal kata Medan. Pembetulannya adalah sebagai berikut.

\section{KES \& KREDIT}

WINNER

Jl. Serdang/Prof. HM. Yamin, No. 634, Medan

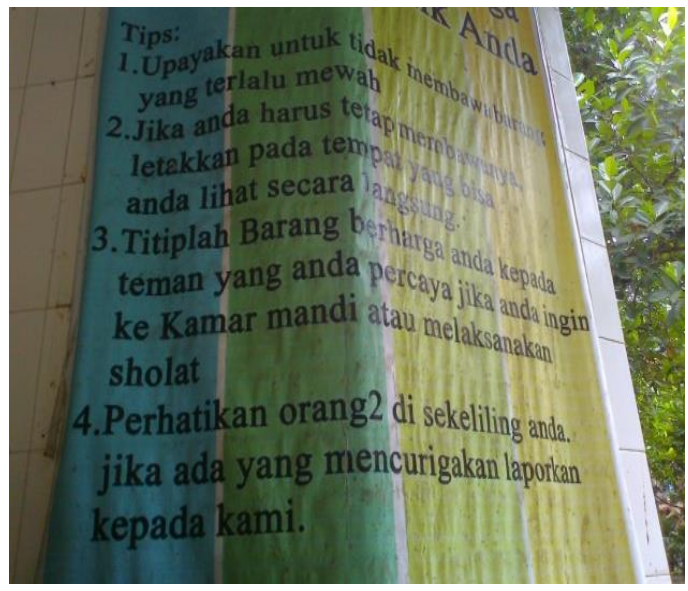

1. Upayakan untuk tidak membawa barang yang terlalu mewah.

2. Jika anda harus tetap membawanya, letakkan pada tempat yang bisa anda lihat secara langsung.

3. Titiplah Barang berharga anda kepada teman yang anda percaya jika anda ingin ke Kamar mandi atau melaksanakan sholat.

4. Perhatikan orang2 di sekeliling anda. Jika ada yang mencurigakan, laporkan kepada kami.

Konstruksi tersebut terdapat pada spanduk. Penulisan spanduk tersebut memiliki empat kesalahan. Pertama, konstruksi tersebut menggunakan huruf kecil pada huruf pertama kata anda. Seharusnya huruf pertama pada kata anda menggunakan huruf kapital karena berdasarkan kaidah ejaan, huruf kapital dipakai sebagai huruf pertama kata ganti Anda (Sugiato, 2013:15). Kedua, konstruksi tersebut 
terdapat penggunaan huruf kapital yang tidak tepat yaitu pada kata Barang dan Kamar. Seharusnya huruf kapital tidak digunakan di huruf pertama kata tersebut karena berdasarkan kaidah ejaan, huruf kapital tidak dipakai sebagai huruf pertama kata yang bukan nama resmi negara, lembaga resmi, lembaga ketatanegaraan, badan, dan nama dokumen resmi (Sugiarto, 2013:12). Ketiga, konstruksi tersebut menggunakan kata serapan yang tidak tepat, yaitu pada kata sholat. Kata sholat tersebut adalah kata serapan dari bahasa Arab Seharusnya kata-kata asing yang telah diserap ke dalam bahasa Indonesia ditulis sesuai dengan ejaan bahasa Indonesia karena berdasarkan kaidah ejaan, penulisan dan pengucapan unsurunsur asing disesuaikan dengan kaidah bahasa Indonesia. Dalam hal itu, diusahakan ejaannya disesuaikan dengan Pedoman Umum Pembentukan Istilah Edisi Ketiga agar bentuk Indonesianya masih dapat dibandingkan dengan bentuk asalnya (Waridah, 2008:16). Dengan demikian, konstruksi tersebut dapat diperbaiki dengan menggantikan huruf $o$ pada kata sholat menjadi huruf $a$ dan menghilangkan huruf $h$. Keempat, konstruksi tersebut menggunakan angka 2 pada bentuk ulang kata orang. Seharusnya dalam penulisan kata ulang di spanduk tidak menggunakan angka 2 karena berdasarkan kaidah ejaan angka 2 dapat digunakan dalam penulisan bentuk ulang untuk keperluan khusus, seperti dalam pembuatan catatan rapat atau kuliah, bentuk ulang ditulis dengan menggunakan tanda hubung di antara unsur-unsurnya (Sugiarto, 2013). Dengan demikian, konstruksi tersebut dapat diperbaiki dengan menggunakan huruf kapital di huruf pertama kata Anda, menggantikan huruf kapital menjadi huruf kecil pada kata barang dan kamar, menggantikan kata sholat menjadi salat, dan menggantikan angka 2 pada kata ulang orang menjadi tanda hubung di antara unsur-unsur pengulangan tersebut. Pembetulannya adalah sebagai berikut.

1. Upayakan untuk tidak membawa barang yang terlalu mewah.

2. Jika Anda harus tetap membawanya, letakkan pada tempat yang bisa Anda lihat secara langsung.

3. Titiplah barang berharga Anda kepada teman yang Anda percaya jika Anda ingin ke kamar mandi atau melaksanakan salat.

4. Perhatikan orang-orang di sekeliling Anda. Jika ada yang mencurigakan, laporkan kepada kami. 


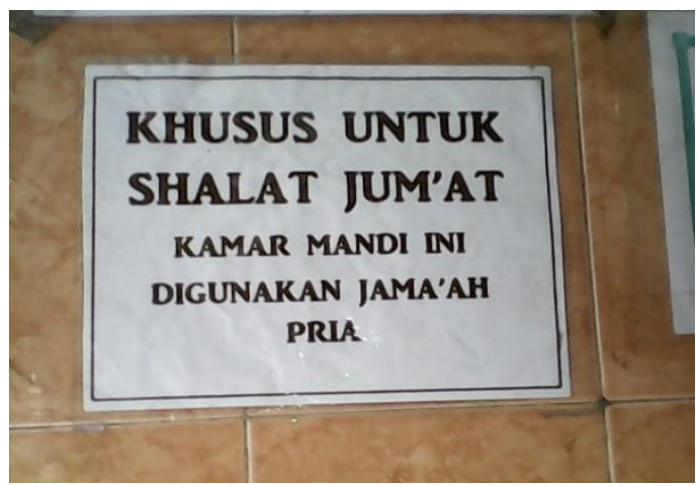

KHUSUS UNTUK

SHALAT JUM'AT

KAMAR MANDI INI

DIGUNAKAN JAMA'AH PRIA

Konstruksi tersebut memiliki dua

kesalahan. Pertama, konstruksi tersebut menggunakan kata serapan yang tidak tepat, yaitu pada kata shalat. Seharusnya kata-kata asing yang telah diserap ke dalam bahasa Indonesia ditulis sesuai dengan ejaan bahasa Indonesia karena berdasarkan kaidah ejaan, penulisan dan pengucapan unsur-unsur asing disesuaikan dengan kaidah bahasa Indonesia. Dalam hal itu, diusahakan ejaannya disesuaikan dengan Pedoman Umum Pembentukan Istilah Edisi Ketiga agar bentuk Indonesianya masih dapat dibandingkan dengan bentuk asalnya (Waridah, 2008:16). Kedua, konstruksi tersebut menggunakan tanda apostrof (') yang tidak tepat, yaitu pada kata jum 'at dan jama'ah. Seharusnya tanda apostrof tidak digunakan pada kata-kata tersebut karena berdasarkan kaidah ejaan, tanda penyingkat menunjukkan penghilangan bagian kata atau bagian angka tahun
(Sugiarto, 2013:59). Jadi, bentuk bakunya adalah Jumat dan Jemaah. Berdasarkan KBBI (2008:592), kata Jumat adalah $n$ hari ke-6 dari jangka waktu satu minggu, sedangkan jemaah adalah $\mathrm{n}$ kumpulan atau rombongan orang beribadah. Dengan demikian konstruksi tersebut dapat diperbaiki dengan menggantikan kata shalat, jum 'at, dan, jama'ah menjadi kata salat, jumat, dan, jemaah. Pembetulannya adalah sebagai berikut.

\section{KHUSUS UNTUK \\ SALAT JUMAT \\ KAMAR MANDI INI \\ DIGUNAKAN JEMAAH PRIA}

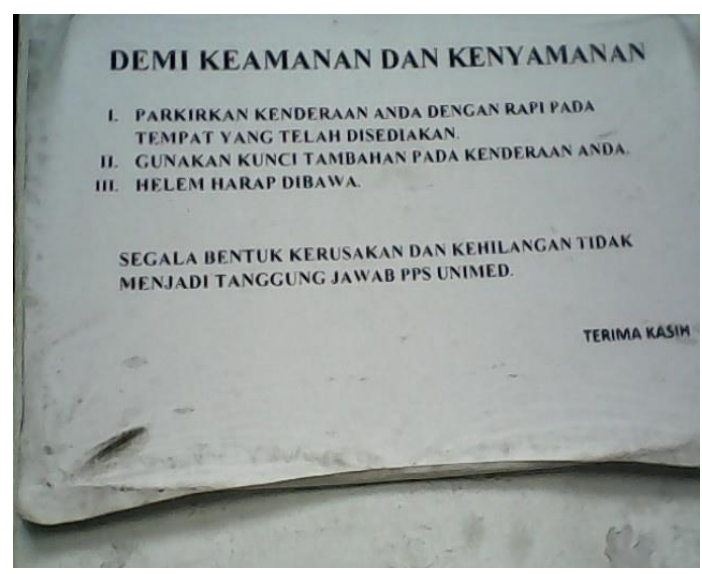

\section{DEMI KEAMANAN DAN \\ KENYAMANAN}

I. PARKIRKAN KENDERAAN ANDA DENGAN RAPI PADA TEMPAT YANG TELAH DISEDIAKAN.

II. GUNAKAN KUNCI TAMBAHAN PADA KENDERAAN ANDA. III. HELEM HARAP DIBAWA. 
Konstruksi tersebut memiliki dua kesalahan. Pertama, konstruksi tersebut menggunakan penomoran yang tidak tepat, yaitu dengan menggunakan angka romawi. Seharusnya penomoran ditulis dengan menggunakan angka Arab karena berdasarkan kaidah ejaan, angka romawi digunakan untuk menyat akan penomoran bab (dalam terbitan atau produk perundang-undangan) dan nomor jalan (Sugiarto, 2013:35). Kedua, konstruksi tersebut salah karena terdapat penulisan kata yang tidak tepat yaitu pada kata kenderaan dan helem. Seharusnya kata-kata tersebut ditulis sesuai dengan kaidah kebahasaan yang berlaku karena berdasarkan kaidah ejaan, sebuah kata harus ditulis dengan menggunakan bahasa baku yang proses penyerapannya mengikuti kaidah kebahasaan yang berlaku (Sugiato, 2013). Dengan demikian, konstruksi tersebut dapat perbaiki dengan menggantikan angka romawi pada penomoran menjadi angka Arab dan kata kenderaan dan helem dapat diganti dengan kata kendaraan dan helm. Berdasarkan KBBI, kata kendaraan adalah $n$ sesuatu yang digunakan untuk dikendarai, sedangkan helm adalah $n$ topi pelindung kepala yang dibuat dari bahan yang tahan benturan. Pembetulan adalah sebagai berikut.

$\begin{array}{lr}\text { DEMI KEAMANAN } & \text { DAN } \\ \text { KENYAMANAN } & \\ \text { 1. PARKIRKAN } & \\ \text { KENDARAAN } & \text { ANDA } \\ \text { DENGAN RAPI } & \text { PADA } \\ \text { TEMPAT YANG } & \text { TELAH } \\ \text { DISEDIAKAN. } & \end{array}$

2. GUNAKAN

KUNCI

TAMBAHAN PADA

KENDARAAN ANDA.

3. HELM HARAP DIBAWA.

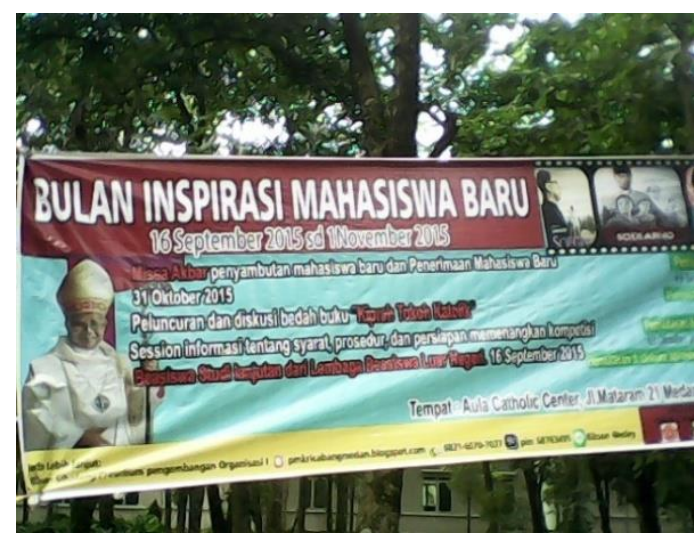

BULAN INSPIRASI MAHASISWA BARU

16 September 2015 sd 1November 2015

Konstruksi tersebut memiliki dua kesalahan. Pertama, konstruksi tersebut salah karena penyingkatan yang tidak tepat. Kesalahan tersebut terletak pada singkatan $s d$. Seharusnya singkatan $s d$ ditulis dengan diikuti tanda titik karena berdasarkan kaidah ejaan, singkatan gabungan kata yang terdiri atas dua 
huruf (lazim digunakan dalam suratmenyurat) masing-masing diikuti oleh tanda titik. Kedua, konstruksi tersebut salah karena ketiadaan spasi antara tanggal dan bulan. Kesalahan tersebut terletak di antara 1 dan November. Seharusnya spasi digunakan di antara tanggal dan bulan karena berdasarkan kaidah ejaan, untuk memisahkan angka dengan kata dipisahkan dengan spasi. Dengan demikian, konstruksi tersebut dapat diperbaiki dengan menambahkan tanda titik pada singkatan $s d$ dan menyisipkan spasi di antara tanggal dan bulan sehingga dapat memudahkan orang lain untuk membacanya. Pembetulannya adalah sebagai berikut.

\section{BULAN INSPIRASI MAHASISWA BARU}

16 September 2015 s.d. 1 November 2015

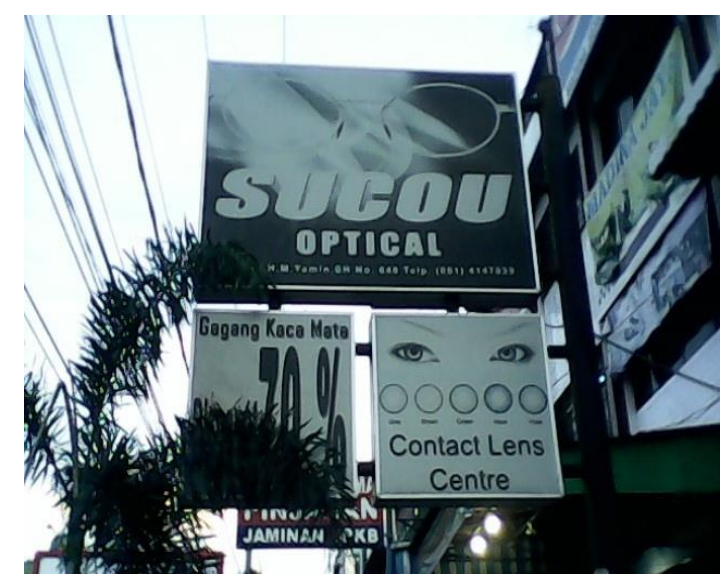

SUCOU

\section{OPTICAL}

Konstruksi tersebut salah karena terdapat penggunaan istilah asing. Kesalahan tersebut terdapat pada kata optical yang merupakan istilah dari bahasa Inggris. Seharusnya kata tersebut ditulis sesuai dengan kaidah ejaan bahasa Indonesia karena berdasarkan kaidah ejaan, penulisan dan pengucapan unsur-unsur asing disesuaikan dengan kaidah bahasa Indonesia (Sugiarto, 2013). Penulisan yang benar adalah tidak menggunakan penambahan fonem /al/, sebab bentuk bakunya adalah optik. Berdasarkan KBBI (2008:985), kata optik adalah $1 a$ berkenaan dengan penglihatan (cahaya, lensa mata), 2 toko peralatan optik (kacamata). Pembetulannya adalah sebagai berikut.

\section{SUCOU OPTIK}

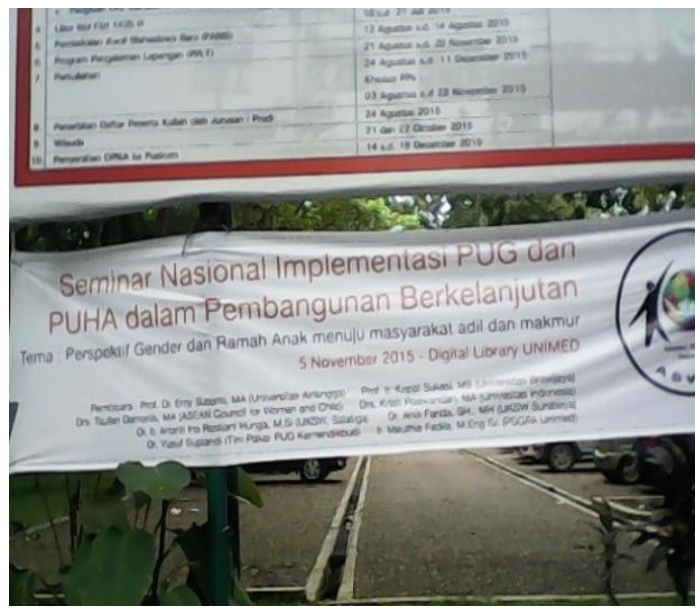


Tema: Perspektif Gender dan Ramah Anak menuju masyarakat adil dan makmur 5 November 2015 - Digital Library UNIMED

Konstruksi tersebut memiliki dua kesalahan. Pertama, konstruksi tersebut salah karena terdapat penggunaan huruf kecil dan huruf kapital yang tidak tepat, yaitu pada huruf pertama kata menuju, masyarakat, adil, dan makmur dan akronim UNIMED. Seharusnya huruf pertama pada kata menuju, masyarakat, adil, dan makmur menggunakan huruf kapital dan akronim UNIMED ditulis dengan menggunakan huruf kapital hanya di huruf pertama akronim tersebut karena berdasarkan kaidah ejaan, huruf kapital dipakai sebagai huruf pertama semua kata (termasuk semua unsur kata ulang sempurna) di dalam judul buku, surat kabar, dan makalah, kecuali kata tugas seperti di, ke, dari, dan, yang, dan untuk yang tidak terletak di posisi awal dan akronim nama diri yang berupa singkatan dari beberapa unsur ditulis dengan huruf awal kapital (Sugiarto, 2013).

Kedua, konstruksi tersebut menggunakan tanda hubung yang tidak tepat. Kesalahan tersebut terletak pada tanda hubung setelah tahun. Seharusnya kata hubung tidak digunakan untuk memisahkan antara waktu dan tempat karena berdasarkan kaidah ejaan, tanda hubung dipakai untuk memperjelas (a) hubungan bagian-bagian kata atau ungkapan dan (b) penghilangan bagian frasa atau kelompok kata (Sugiarto, 2013:49). Dengan demikian, konstruksi tersebut dapat diperbaiki dengan menggantikan huruf kecil pada huruf pertama kata menuju, masyarakat, adil, dan makmur menjadi huruf kapital, menggantikan huruf kapital pada akronim UNIMED menjadi huruf kecil, kecuali pada huruf pertama pada akronim tersebut dan menggantikan tanda hubung menjadi preposisi $d i$. Pembetulannya adalah sebagai berikut.

Tema: Perspektif Gender dan Ramah Anak Menuju Masyarakat Adil dan Makmur 5 November 2015 di Digital Library Unimed

\section{KESIMPULAN}

Berdasarkan data-data yang ditemukan di lapangan dan hasil analisis dapat disimpulkan bahwa kesalahan berbahasa Indonesia pada penulisan media luar ruang di Kota Medan masih banyak dijumpai yang belum/tidak sesuai dengan kaidah bahasa Indonesia yang baik dan benar. Bentuk-bentuk kesalahan penulisan di media luar ruang di Kota Medan meliputi kesalahan penulisan tanda baca, kesalahan 
penulisan singkatan, kesalahan penggunaan huruf kapital, kesalahan pemilihan kata, dan kesalahan penulisan ejaan.

\section{SARAN}

Tidak ada alasan kita untuk malu memakai bahasa Indonesia, banyak negara yang menggunakan bahasa Indonesia sebagai matakuliah untuk bahasa asing di kampus.. Sebagai bangsa yang besar kita harus menghargai, bangga dan cinta terhadap bahasa Indonesia. Kita harus berusaha untuk memperbaiki kesalahan bahasa yang kita lakukan selama ini terutama untuk bahasa dalam media ruang. Bangsa yang besar adalah bangsa yang mencintai bahasa persatuan. Untuk itu pakailah bahasa Indonesia sesuai dengan kaidah yang baik dan benar 


\section{Daftar Pustaka}

Chaer, Abdul. 2006. Tata Bahasa Praktis Bahasa Indonesia. Jakarta: Rineka Cipta.

Depdiknas. 2008. Kamus Besar Bahasa Indonesia Pusat Bahasa. Jakarta: PT Gramedia Pustaka Utama.

Departemen Pendidikan dan Kebudayaan. 2009. Pedoman Umum Ejaan Bahasa Indonesia yang Disempurnakan. Jakarta: PT Gramedia Widiasarana.

Permendiknas. 2009. Ejaan Bahasa Indonesia yang Disempurnakan (EYD Terbaru).Yogyakarta: Pustaka Timur.

Setyawati, Nanik. 2010. Analisis Kesalahan Berbahasa Indonesia. Surakarta: Yuma Pustaka. Sugiarto, Eko. 2013. Master EYD Edisi Baru. Yogyakarta: Suaka Media.

Tarigan, Henry Guntur. Tanpa Tahun. Pengajaran Ejaan Bahasa Indonesia. Bandung: Angkasa.

Waridah, Ernawati. 2008. EYD dan Seputar Kebahasa-Indonesiaan. Jakarta: Kawan Pustaka.

Widjono. 2012. Bahasa Indonesia. Jakarta: Kompas Gramedia.

Rahardian, Ema. 2014. Analisis Penggunaan Bahasa Dalam Papan Imbauan Di Kabupaten Demak. Volume 10, Nomor 2, November 2014. Semarang:Balai Bahasa Jawa Tengah 